\title{
Rancang Bangun Aplikasi Game Avatar dengan Menerapkan Gamifikasi untuk Meningkatkan Minat Pengunjung Objek - Objek Bersejarah di Surabaya
}

\author{
Benedictus Arya Binarsatya dan Nisful Asrul Sani \\ Departemen Sistem Informatika, Fakultas Teknologi Informasi dan Komunikasi, \\ Institut Teknologi Sepuluh Nopember (ITS) \\ e-mail: soni@is.its.ac.id
}

\begin{abstract}
Abstrak-Pada masa kini, teknologi informasi yang semakin berkembang sehingga menciptakan kemudahan untuk mendapatkan informasi hanya dari komputer dan handphone. Untuk mengetahui tempat tempat tertentu cukup melihat gambar dari internet saja, sehingga orang tidak perlu ke tempat tersebut secara langsung. banyak tempat tempat bersejarah yang jarang dikunjungi orang. Gamifikasi adalah metode desain menggunakan konsep sebuah permainan pada kegiatan non game. Dengan memanfaatkan gamifikasi, pengunjung dapat diajak untuk lebih tertarik dalam berkunjung ke tempat tempat bersejarah secara langsung dengan menerapkan game mechanic yang terdapat pada metode gamifikasi. Dalam studi ini, akan dibuat sebuah aplikasi berupa game yang bertujuan agar orang melakukan kegiatan nyata, yaitu mengunjungi tempat tempat bersejarah di kota surabaya. sehingga tingkat kepedulian orang orang akan tempat-tempat bersejarah meningkat.
\end{abstract}

Kata Kunci-Avatar, Gamifikasi, Game, Tempat Bersejarah.

\section{PENDAHULUAN}

$\mathrm{T}$ EMPAT bersejarah disuatu daerah telah menjadi salah satu aset daerah yang saat ini hampir dilupakan. Banyak upaya yang telah dilakukan pemerintah dalam mempertahankan aset tersebut, salah satunya dengan mengadakan kegiatan Lawatan Sejarah Tingkat Nasional (Lasenas) [1] pada tahun 2003, tetapi hal ini tidak berlangsung lama karena adanya teknologi informasi yang semakin canggih.

Kemajuan sebuah teknologi informasi saat ini dapat menciptakan berbagai kemudahan. Salah satunya pengguna bisa mendapatkan sebuah informasi hanya dari sebuah komputer dan handphone. Sehingga untuk mengetahui tempat - tempat tertentu cukup melihat gambar dari internet tanpa perlu datang ke tempat tersebut secara langsung. Salah satunya tempat - tempat bersejarah dimana dengan kemudahan yang diberikan oleh teknologi informasi saat ini, banyak tempattempat bersejarah tersebut yang sangatjarang atau bahkan tidak pernah dikunjungi orang baik dari kalangan tua sampai kalangan muda. Untuk itu diharapkan munculnya minat generasi sekarang ini untuk mengunjungi tempat bersejarah melalui sosial media yang sangat dekat dengan kehidupan sosial masyarakat.

Dengan memanfaatkan kemajuan teknologi, maka dibuatlah sebuah aplikasi di mana pemain akan mendapatkan sebuah reward, dengan mengunjungi tempat-tempat bersejarah. Para pemain dapat meningkatkan reward mereka dengan terus mengunjungi tempat-tempat bersejarah yang berbeda-beda.
Kemudian mereka juga dapat membagikan hasil pencapian yang didapat melalui sosial media, maupun dalam aplikasi itu sendiri.

Untuk dapat membuat aplikasi tersebut maka dibutuhkan beberapa rumusan masalah antara lain, cara meningkatkan minat berkunjung masyarakat pada tempat-tempat bersejarah, cara membuat aplikasi menggunakan metode gamifikasi dan cara membagikan hasil pencapaian reward dalam sebuah aplikasi yang menggunakan metode gamifikasi.

Selain rumusan masalah dalam membuat aplikasi juga harus ditentukan batasan masalah, tujuan studi dan manfaat studi. Batasan masalah harus ditentukan untuk dapat memfokuskan proses pembuatan aplikasi antara lain, aplikasi yang dibuat menggunakan basis android, tempat - tempat bersejarah yang dipilih hanya di kota Surabaya, tempat bersejarah yang dimaksud adalah monument dan museum dan studi ini berfokus pada pengembangan aplikasi dari perancangan hingga pengujian aplikasi. Sedangkan tujuan dari studi ini adalah mengembangkan aplikasi berbasis android yang dapat digunakan untuk meningkatkan minat orang mengunjungi sebuah tempat bersejarah secara langsung dan meningkatkan pengetahuan seseorang tentang sebuah sejarah. Aplikasi yang dihasilkan diharapkan mampu meningkatkan pengunjung serta meningkatkan interaksi sosial secara langsung dengan bertatap muka.

Dengan melengkapi poin-poin di atas, maka aplikasi ini diharapkan aplikasi ini dapat memberikan manfaat antara lain, meningkatkan minat masyarakat terhadap tempat - tempat bersejarah, meningkatkan interaksi social secara langsung, membantu para wisatawan untuk lebih mengenal tempat tempat wisata bersejarah, dan menjadi langkah awal dalam membuat aplikasi selanjutnya.

\section{TINJAUAN PUSTAKA}

\section{A. Gamifikasi}

Istilah gamifikasi sebenarmya berasal dari industry media digital. Pertama kali dikenalkan istilah ini pada awal tahun 2008, namun istilah gamifikasi ini mulai popular pada paruh kedua tahun 2010. Ketika beberapa pelaku industry dan beberapa konferensi mempopulrkannya. Gamifikasi merupakan sebuah konsep mengaplikasikan Gamifikasi adalah metode yang digunakan untuk mengembangkan aplikasi non permainan dengan metode dan cara berpikir permainan. 
Tabel 1.

Tahap Pengembangan

\begin{tabular}{ll}
\hline \hline No & Fungsional \\
\hline 1 & Menampilkan Peta \\
2 & Menghubungkan aplikasi dengan server \\
3 & Mencari lokasi pengguna \\
4 & Menampilkan reward atau penghargaan \\
5 & Menghitung perolehan poin \\
6 & Menghitung peringkat \\
7 & Menampilkan daftar tempat bersejarah \\
8 & Menampilkan detail tempat bersejarah \\
9 & Menampilkan lokasi tempat bersejarah di peta \\
10 & Memberikan penghargaan atau reward ketika pengguna \\
& dating ke tempat bersejarah \\
\hline \hline
\end{tabular}

gamifikasi dimaksudkan untuk meningkatkan minat pengguna untuk lebih berkontribusi dalam penyelesaian masalah [2].

Tujuan dari gamifikasi adalah untuk meningkatkan keinginan alami manusia untuk bersosialisasi, berkompetisi, mendapatkan prestasi, belajar, menguasai sesuatu, mendapatkan status, dan ekspresi diri. Dengan memanfaatkan keinginan alami manusia tersebut strategi gamifikasi menggunakan imbalan kepada pemain karena telah menyelesakan tugas-tugas yang telah diberikan atau membuat pemain untuk bersaing dengan pemain lain. Imbalan yang diberikan dapat berupa point, badge, level, progress bar, benda virtual, atau membuat pencapaian pemain dapat dilihat pemain lain. Ranking dapat dimanfaatkan agar pemain merasa bersaing dengan pemain yang lain [2].

\section{B. Game Mechanic}

Game mechanic adalah mekanisme dalam game yang digunakan desainer sebagai reward bagi aktifitas yang dilakukan pelanggan, karyawan atau pengguna lain [3].

Setiap game mechanic memiliki karakteristik yang berbeda untuk setiap tipe player yang berbeda. Player dibagi menjadi 4 kategori:

1. Achievers: Pemain yang ingin berada di posisiteratas

2. Explorers: Pemain yang mencari sesuatu yang baru

3. Socializers:Pemain yang berinteraksi dengan pemain lain

4. Killers: Pemain yang mengeliminasi pemain lain

Didalam game mechanic juga memiliki karakteristik yang dapat dibagi menjadi 3:

1. Behavioral:

Behavorial adalah bagian yang berfokus pada pembentukan perilaku dan sifat manusia. Behavorial dapat dibagi dalam beberapa bagian antara lain, discovery, ownership dan status. Discovery adalah pemain suka melakukan explorasi untuk menemukan sesuatu. Discovery dapat didukung dengan fitur dalam game dimana pemain dapat menjelajah untuk menemukan sesuatu yang baru. Dalam gamifikasi hal ini bisa diterapkan agar pemain mau mencari halaman baru, membaca berita baru, dan melakukan penerapan lain Discovery dapat mendukung tipe pemain Explorers dan Achievers.

Ownership adalah fitur dalam game dimana pemain dapat memiliki sesuatu, misalkan hewan peliharaan. Ownership dapat meningkatkan loyalitas pemain dengan membuat pemain merasa memiliki sesuatu yang berharga. Ownership dapat mendukung tipe pemain Achievers, Explorers, Socializers, Killers. Sedangkan status, adalah ranking atau level dari pemain. Pemain akan semakin termotivasi untuk terus mencapai level atau status yang lebih tinggi. Status biasanya digambarkan dengan badge dan poin yang digunakan untuk menunjukan pencapaian dan pengalaman dari pemain. Status dapat mendukung tipe pemain Achievers, Socializers, Killers.

2. Feedback:

Feedback adalah proses untuk memberikan informasi perubahan State kepada pemain. Feedback juga bisa berbentuk nilai yang ditampilkan dalam leaderboard, maupun achievement dalam elemen gamifikasi. Feedback sangat berguna dalam meningkatkan motivasi maupun menunjukkan tingkat ketertarikan pada sebuah permainan.

3. Progression:

Progession merupakan proses untuk membuat struktur pencapaian atau kemampuan pengguna. Progession juga meliputi dua aspek penting yaitu achievement dan level. Achievement adalah representasi secara virtual bahwa pemain telah menyelesaikan sesuatu. Achievement dapat disimbolkan dengan berbagai hal, salah satunya dengan badge seperti yang ada pada foursquare. Achievement juga dapat memberikan motivasi bagi tipe pemain Achievers, Explorers, Killers.

Berikutnya adalah level yang merupakan system dimana player akan diberi sebuah hadiah berupa peningkatan poin.dengan naiknya level bias anya akan didapat fitur atau kemampuan baru sesuai dengan nilai level pemain. Level merupakan komponen yang memiliki tingkat motivasi tertinggi dalam game. Level dapat meningkatkan motivasi tipe pemain Achievers, Explorers, Killers.

\section{Tempat Bersejarah di Surabaya}

Kota Surabaya adalah ibukota Provinsi Jawa Timur, Indonesia. Surabaya merupakan kota terbesar kedua di Indonesia setelah Jakarta, dengan jumlah penduduk metropolisnya yang mencapai 3 juta jiwa, Surabaya merupakan pusat bisnis, perdagangan, industri, dan pendidikan di kawas an Indonesia timur. Surabaya terkenal dengan sebutan Kota Pahlawan karena sejarahnya yang sangat diperhitungkan dalam perjuangan merebut kemerdekaan bangsa Indonesia dari penjajah. Kata Surabaya konon berasal dari cerita mitos pertempuran antara sura (ikan hiu) dan baya (buaya) dan akhirnya menjadi kota Surabaya.

- Monumen Kapal Selam

- Monumen Mayangkara

- Monumen Bambu Runcing

- Monumen Jales Veva Jaya Mahe

- Monumen Jendral Soedirman

- Monumen Bhayangkara

- Museum Negeri Mpu Tantular

- Museum House of Sampoerna

- Museum Nahdlatul Ulama

- Museum 45

- Patung Karapan Sapi

- Tugu Pahlawan

\section{PEMBAHASAN}

Pembuatan Rancang Bangun Aplikasi Game Avatar ini dilakukan dengan berbagai tahap, diantaranya:

1) Melakukan penelitian dan telaah terkait dengan penelitian sejenis atau penerapan gamifikasi pada teknologi mobile gaming. 
2) Melakukan analis a tentang kebutuhan fungsional pada aplikasi yang akan dikembangkan

3) Pembuatan desain User Interface aplikasi

4) Pengujian Implementasi aplikasi dengan emulator, untuk menguji kinerja aplikasi

\section{A. Melakukan telaah terkait dengan penelitian sejenis.}

Tahap ini menghasilkan berbagai macam informas $i$ mengenai tipe-tipe gamifikasi yang diterapkan dalam rancang bangun aplikasi avatar. Dengan begitu, proses pengembangkan aplikasi dapat dilakukan dengan lebih terstruktur dan sistematis.

\section{B. Melakukan analisa tentang kebutuhan fungsional}

Tahap ini menghasilkan daftar kebutuhan fungsional yang akan diimplementasikan pada aplikasi avatar yang akan dikembangkan. (Tabel 1)

\section{Pembuatan desain User Interface}

Pada tahap ini dilakukan pengerjaan desain dan layout untuk tampilan pada aplikasi avatar.

\section{Pengujian implementasi aplikasi.}

Tahapan ini dilakukan dengan menggunakan bantuan untuk melakukan pengujian dan implementasi dari daftar kebutuhan aplikasi yang telah ditulis pada tahap sebelumnya.

\section{KESIMPULAN/RINGKASAN}

Kesimpulan diambil secara menyeluruh pengerjaan Studi ini mulai dari analisis strategi gamifikasi adalah:

1) Reward atau penghargaan diharapkan lebih mempengaruhi minat pengguna aplikasi untuk meningkatkan pencapaiannya, karena dengan menampilkan reward atau penghargaan bisa meningkatkan perasaan bangga para pengguna aplikasi.

2) Keaktivitan pengguna satu dengan yang lain mempengaruhi minat pengguna aplikasi ini untuk terus berkunjung ke tempat - tempat bersejarah.

3) Sebagian besar masyarakat Surabaya telah menggunakan smartphone, sehingga, dengan membuat aplikasi yang menerapkan sistem gamifikasi, dapat memberikan pengalaman yang lebih interaktif pada pengguna. Sehingga lebih meningkatkan minat pengguna untuk mengunjungi tempat-tempat bersejarah.

4) Gamifikasi dapat menyajikan sebuah pembelajaran dengan cara yang berbeda dan menyenangkan.

\section{DAFTAR PUSTAKA}

[1] Y. Erwianisya, "Pengaruh Penggunaan Model Lawatan Sejarah Terhadap Hasil Belajar Sejarah Siswa Kelas Vii Smp Negeri 3 Magelang T ahun Ajaran 2014/2015," Semarang.

[2] P. Octafiani, "Aplikasi Pembelajaran Matematika Dengan Konsep Gamifikasi Berbasis Android,” Samarinda, 2017.

[3] M. Farozi, "Perancangan Sistem Informasi Penilaian Kinerja Sumber Daya Manusia Menggunakan Metode Gamifikasi,"Yogyakarta. 